Vol. 24, No. 3, Juli 2021, hlm. 447-455

p-ISSN: 1410-9344; e-ISSN: 2549-5631

WARTA LPM

\title{
Pemberdayaan Masyarakat dengan Pendekatan Qaryah Tayyibah pada Desa Datar Kecamatan Sumbang Kabupaten Banyumas
}

\author{
${ }^{1}$ Makhrus, ${ }^{2}$ Wage, ${ }^{3}$ A. Sulaeman \\ 1,2,Program Studi Hukum Ekonomi Syariah, Fakultas Agama Islam Universitas Muhammadiyah Purwokerto \\ ${ }^{3}$ Program Studi Pendidikan Agama Islam, Fakultas Agama Islam Universitas Muhammadiyah Purwokerto \\ Email : ${ }^{1}$ makhrus.ahmadi@gmail.com, ${ }^{2}$ wagefsyah.2010@gmail.com, ${ }^{3}$ sulaeman.ump@gmail.com
}

\section{Article Info}

Submitted: 18 November 2020

Revised: 9 March 2021

Accepted: 31 May 2021

Published: 20 July 2021

Keywords: Community development; qaryah thayyibah; multi perspective
Kata kunci: Pemberdayaan masyarakat; qaryah thayyibah; multi perspektif

\begin{abstract}
Empowerment of rural communities generally aims to improve the standard of living of rural communities. The aim of implementing community service carried out by the implementation team is community empowerment with the qaryah thayyibah approach that is able to provide a multi-perspective educational impact to the community through community empowerment programs. Partners in this activity are Datar Village, Sumbang District, Banyumas Regency. The method used in this activity focuses on three programs namely religious, youth, health, and community economy in the form of training, outreach, and assistance (advocacy). The results in the process of community service activities indicate that religious assistance is carried out with zakat management training. The material in this activity is divided into two parts namely zakat law and zakat management. Youth assistance is manifested in the form of socialization of infectious diseases and the dangers of drugs for adolescents and the development of interests and talents carried out in a way of discussion with the management team of Garuda Datar team which ended with the provision of foot ball equipment. While community health and economic assistance manifested in the form of activities to increase the capacity of posyandu cadres, while to improve the welfare of the community's living standards is carried out with food diversification training aimed at becoming an alternative food source outside the main foodstuffs.
\end{abstract}

Abstrak
Pemberdayaan masyarakat pedesaan umumnya bertujuan dalam
meningkatkkan taraf hidup masyarakat desa. Tujuan pelaksanaan
pengabdian masyarakat yang dilakukan oleh tim pelaksana adalah
pemberdayaan masyarakat dengan pendekatan qaryah thayyibah
yang mampu memberikan dampak edukatif multi perspektif kepada
masyarakat melalui program pemberdayaan masyarakat. Mitra dalam
kegiatan ini adalah Desa Datar, Kecamatan Sumbang, Kabupaten


Banyumas. Metode yang digunakan dalam kegiatan ini memfokuskan tig program yakni keagamaan, kepemudaan, dan kesehatan dan ekonomi masyarakat dalam bentuk pelatihan, sosialisasi, dan pendampingan (advokasi). Hasil dalam proses kegiatan pengabdian masyarakat ini menunjukkan bahwa pendampingan keagamaan dilakukan dengan pelatihan pengelolaan zakat. Materi dalam kegiatan ini dibagi menjadi dua bagian yakni hukum zakat dan manajemen pengelolaan zakat. Pendampingan kepemudaan yang termanifestasi dalam bentuk sosialisasi penyakit menular dan bahaya narkoba bagi remaja dan pengembangan minat dan bakat yang dilakukan cara diskusi dengan pengurus tim kesebelasan Garuda Datar yang diakhiri pemberian perangkat sepak bola. Sementara pendampingan kesehatan dan ekonomi masyarakat yang termanifestasi dalam bentuk adanya kegiatan peningkatan kapasitas kader posyandu, sedangkan untuk peningkatan kesejahteraan taraf hidup masyarakat dilakukan dengan pelatihan diversifikasi pangan yang bertujuan menjadi sumber pangan alternatif diluar bahan pangan utama.

\section{PENDAHULUAN}

Pemberdayaan masyarakat pedesaan umumnya bertujuan dalam meningkatkan taraf hidup masyarakat desa, hal ini dilakukan agar tingkat kemiskinan, minimnya akses pendidikan dan kesehatan, dan adanya ketimpangan sosial dapat tangani oleh pemerintah dan masyarakat secara umum. Implikasinya, masyarakat dapat berdaya tanpa harus melakukan urbanisasi ke kota untuk meningkatkan taraf hidup. Maka, adanya pemberdayaan masyarakat dengan melibatkan seluruh lapisan masyarakat dan pemerintah senantiasa akan mampu menangani permasalahan mendasar masyarakat pedesaan.

Desa Datar, Kecamatan Sumbang, Kabupaten Banyumas secara geografis memiliki potensi besar, khususnya dalam pengembangan dan pemberdayaan pertanian, hal ini dikarenakan mayoritas warganya berprofesi sebagai buruh, petani, pedagang, pengrajin, serta terdapatnya embung yang dalam jangka panjang dapat dijadikan desa agrowisata, selain itu di Desa Datar juga terdapat situs Batu Guling yang telah berusia ratusan tahun dan saat ini dalam proses pengembangan sebagai objek wisata religi sekaligus menjadi salah satu cagar budaya di Kabupaten Banyumas.

Potensi besar yang dimiliki Desa Datar sebenarnya telah dikaji oleh beberapa peneliti, salah satunya berkaitan dengan pemberdayaan lele dumbo yang mampu menopang kebutuhan ekonomi masyarakat (Abulias, MN. Utarini, SR. Winarti, 2014), potensi peternakan dalam penggemukan dan pembesaran sapi potong (Sodiq \& Yuwono, 2016), dan upaya dalam mengukur usaha dalam peningkatan taraf kesehatan (Dardjito, Endo. Nurcahyo, 2010). Dari penelitian tersebut, menunjukkan bahwa terdapat potensi besar yang dapat dikembangkan di Desa Datar yang mampu meningkatkan nilai ekonomi usaha masyarakat, namun di sisi lain pembangunan sumber daya manusia melalui pendekatan agama juga tidak kalah penting, sebab sebagian besar masyarakat Desa Datar beragama Islam. Salah satu, yang dalam proses pemberdayaan masyarakat di Desa Datar dengan pendekatan yang lebih persuasif dan filosofis seperti qaryah thayyibah.

Qaryah thayyibah adalah suatu perkampungan atau desa yang menjalankan ajaran Islam secara kaffah dalam segala aspek kehidupan yang meliputi akhlak, ibadah, dan muamalah (PP Aisyiyah, 2012). Artinya, qaryah thayyibah merupakan perkampungan/ desa yang masyarakatnya menjalankan ajaran Islam, baik dalam konteks vertikal terhadap Allah (hablum minallah) dan secara horisontal di masyarakat (hablum minannas). Sikap dan tindakan relasional tersebut dipraktikkan ke dalam berbagai aspek kehidupan, baik dalam bidang aqidah, ibadah, akhlak, dan muamaah duniawiyah. 
Dalam ajaran Al-Qur.'an mengenai keberadaan perkampungan ideal tersebut tertuang dalam QS. Al A'raf: 96 tentang masyarakat yang tentram dan damai, QS. Saba': 15 tentang masyarakat yang pandai mensyukuri nikmat, QS An Nahl: 18 tentang menghidupkan semangat, $A l M a^{\prime}$ un yang intinya senang bekerja sama dalam kebaikan, QS. Al Imran: 110 tentang sikap toleransi dan menjaga persatuan dan kesatuan, QS. Al An'am: 159 tentang tentang jamaah, seperti shaff dalam shalat, QS. Shaf: 4 tentang semangat amar ma'ruf nahi munkar, QS. Ar Rum: 21 tentang warga yang memiliki etos kerja yang tinggi, dan QS. Ar Rad: 11 tentang menyadari pentingnya pendidikan.

Tujuan adanya qaryah thayyibah menginginkan agar masyarakat desa khususnya perempuan menjadi seorang ibu rumah tangga yang mandiri dengan memiliki usaha yang dapat meningkat kejehateraan ekonomi, kesadaran atas pentingnya kesehatan, berpendidikan yang layak, dan hubungan sosial yang baik (Puspita, 2016), sedangkan karakteristik qaryah thayyibah yakni : (1) menjadikan masjid sebagai tempat ibadah, pelayanan sosial, dan pusat kegiatan masyarakat, (2) tingkat pendidikan yang maju, (3) adanya berbagai usaha yang dilakukan masyarakat untuk meningkatkan kesejahtraan ekonomi, (4) derajat kesehatan masyarakat yang tinggi, baik secara fisik, psikis, dan lingkungan, dan (5) ada hubungan yang harmonis di masyarakat, baik secara sosial, kepedulian sosial, dan kesadaran terhadap hukum dan politik yang tinggi. Dalam konteks ini keberadaan rumah tangga memiliki peranan penting, sebab keluarga menjadi cerminan sebuah negara yang makmur dan sejahtera tentunya adalah keluarga yang harmonis, di mana masing-masing anggota menjalankan hak dan kewajibannya secara proporsional yang kemudian sebagai keluarga sakinah (Adawiah, 2013). Oleh sebab itu, meski secara tidak langsung secara institusional kelembagaan telah terdapat sekolah alternatif yang menggunakan nama qaryah thayyibah yang mampu menawarkan pendidikan bermutu dan murah berbasis komunitas (Bahrudin, 2007).

Pemberdayaan memiliki padanan makna dengan pendayagunaan yang berarti mengusahakan sesuatu agar mampu mendatangkan hasil dan manfaat, selain itu, pemberdayaan (empowerment) juga berasal dari power yang berarti kekuatan dan kekuasaan. Sementara pemberdayaan menurut Robert Dahl adalah pemberian kuasa untuk menguasai atau mengontrol manusia baik individu ataupun kelompok untuk berpartisipasi dalam keputusan yang menyangkut diri dan komunitasnya (Dahl, 1989). Maka, dengan demikian masyarakat memiliki hak untuk menentukan pilihan apa saja yang hendak dilakukan untuk mengembangkan diri dan memutuskan pilihannya. Sedangkan masyarakat adalah sejumlah manusia dalam arti yang seluas-luasnya dan terikat oleh suatu kebudayaan yang mereka anggap sama. Oleh sebab itu, pemberdayaan masyarakat bermakna mengembangkan kondisi dan situasi sedemikian rupa, sehingga masyarakat memiliki daya dan kesempatan untuk mengembangkan kehidupannya tanpa adanya kesan perkembangan tersebut hasil kekuatan eksternal dengan memposisikan masyarakat harus sebagai subyek bukan objek (Makhrus, 2018).

Kondisi keagamaan masyarakat Desa Datar sebagaimana lazimnya masyarakat desa umumnya kultur keagamaannya bercorak puritan, sehingga potensi pratana sosial keagamaan Islam yang dalam ini zakat, masih belum tergali potensinya secara optimal, meskipun pada dasarnya hal tersebut dapat dimanfaatkan untuk pengembangan masyarakat berbasis zakat, sebab selama ini praktik pengelolaan zakat di Desa Datar masih dilakukan secara konvensional dengan pengumpulan dan pendistribusian zakat dilakukan pada saat bulan Ramadan, berbasis masjid, dan kepanitiaan temporer, sehingga belum sesuai dengan Undang-Undang No. 23/2011 bahwa zakat harus dikelola secara terlembaga.

Keberadaan organisasi kepemudaan Karang Taruna Desa Datar yang awalnya kurang aktif, namun belakangan mulai aktif kembali dengan berbagai pendampinngan yang dilakukan oleh perangkat desa dan dukungan masyarakat. Selama ini permasalahan yang dihadapi Karang Taruna Desa Datar lebih pada persoalan internal kepengurusan dan aktivitas di luar organisasi, maka setelah adanya pendampingan intensif Karang Taruna Desa Datar kembali bangkit. Namun, ancaman 
lain yang harus dihadapi pemuda Desa Datar adalah penyebaran obat-obatan terlarang, hal tersebut ditandai oleh ditangkapnya dua kurir sabu-sabu yang kemudian terancam hukuman mati setelah ditangkap di Kecamatan Sumbang (jateng.antaranews.com, n.d.), sehingga hal ini membutuhkan pendampingan dalam bentuk sosialisasi tentang larangan penyalahgunaan obat-obatan terlarang. Sementara kondisi kesejahteraan warga Desa Datar yang sebagian warganya berprofesi sebagai buruh, petani, pedagang, dan pengrajin. Implikasi dari profesi informal ini, membutuhkan pendampingan untuk meningkatkan kesejahteraan masyarakat Desa Datar dari sisi pembangunan ekonominya, salahnya dengan meningkatkan diversikasi pangan yang dapat dilakukan secara industri rumahan berbasis rumah tangga.

Tujuan pelaksanaan pengabdian masyarakat ini untuk memberikan pemahaman yang komprehensif mengenai pendekatan dan aplikasi qaryah thayyibah, khususnya dalam bidang keagamaan, kepemudaan, kesehatan dan kesejahteraan masyarakat di Desa Datar memiliki 3 RW dan 9 RT yang memungkinkan proses interaksi dalam proses pemberdayaan masyarakat berbasis desa dapat berjalan secara optimal, baik jangka pendek maupun jangka panjang.

\section{METODE}

Guna menjawab permasalahan yang dihadapi oleh masyarakat Desa Datar Kecamatan Sumbang Kabupaten Banyumas, maka tim pelaksana melakukan koordinasi untuk melakukan pemecahan terhadap permasalahan yang dihadapi yang hasilnya memfokuskan tiga program, yakni: pertama, pedampingan keagamaan berkaitan dengan pengelolaan zakat dengan bekerjasama dengan Takmir Masjid/Musala dan RT Se-Desa Datar. Kedua, pendampingan kepemudaan yang bekerjasama dengan karang taruna dan tim Sepak Bola Garuda Datar. Ketiga, pendampingan kesehatan dan ekonomi masyarakat bekerjasama dengan Posyandu dan PKK Desa Datar.

Ketiga program tersebut dilaksanakan dengan menggunakan pendekatan qaryah thayyibah, sedangkan metode yang digunakan sebagai berikut:

a. Pendampingan Keagamaan

Pendampingan yang dilakukan dengan melakukan pelatihan pengelolaan zakat pada tanggal 21 Mei 2019 bersamaan dengan bulan puasa. Materi dalam kegiatan ini dibagi menjadi dua bagian yakni hukum zakat dan manajemen pengelolaan zakat. Upaya dalam meningkatkan pemahaman berzakat dilakukan dengan memberikan materi ke dalam beberapa sesi materi dengan menggunakan metode parsipatoris dialogis, di mana para peserta pelatihan diberikan kesempatan untuk mengadapakan tanya jawab dan sharing dengan pemateri terkait materi yang disampaikan, sehingga terjadi dialog antar pemateri dengan peserta pelatihan.

b. Pendampingan Kepemudaan

Pendampingan kepemudaan di Desa Datar dilakukan dengan adanya sosialisasi penyakit menular dan bahaya narkoba bagi remaja yang hampir menjadi permasalahan bersama di berbagai tempat, pemateri berasal dari Badan Narkotika Nasional (BNN), Babinkamtibmas, dan Babinsa Kabupetan Banyumas yang dilaksanakan

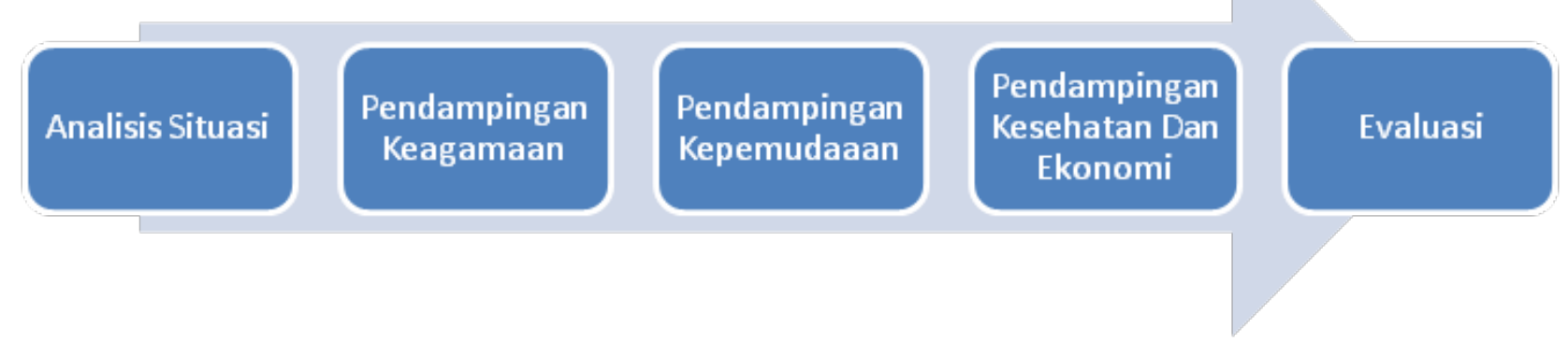

Gambar 1. Proses Kegiatan Pengabdian 
pada bulan November 2019, selain itu proses pendampingan dilakukan dengan adanya pengembangan minat dan bakat dilakukan dengan cara diskusi dengan pengurus tim kesebelasan Garuda Datar yang diakhiri pemberian perangkat sepak bola.

c. Pendampingan Kesehatan dan Ekonomi Masyarakat

Pendampingan dilakukan dengan dilaksanakannya kegiatan peningkatan kapasitas kader Posyandu Desa Datar. Adanya kegiatan ini bertujuan agar tingkat kesehatan masyarakat, khususnya balita dan batita menjadi lebih baik yang ditandai dengan tumbuh dan kembang anak yang positif. Sementara peningkatan kesejahteraan taraf hidup masyarakat dilakukan dengan pelatihan diversifikasi pangan dengan tujuan agar masyarakat Desa Datar dapat memanfaatkan sumber pangan alternatif di luar bahan pangan utama (padi). Proses kegiatan ini para peserta diberikan materi oleh Pokja 3 PKK Desa Datar, kemudian para peserta diberikan kesempatan untuk mempraktikan pangan alternatif tersebut ke dalam berbagai bahan olahan makanan dengan tujuan setelah pelaksanaan pelatihan diversifikasi pangan, para peserta menerapkannya dan dalam jangka panjang menjadi sumber penghasilan berbasis industri rumah tangga. Proses kegiatan ini dilaksanakan pada bulan November 2019.

\section{HASIL DAN PEMBAHASAN}

Pemberdayaan masyarakat berbasis qaryah thayyibah memang membutuhkan banyak peran serta masyarakat, pemerintah, dan lembaga sosial. Sebab proses qaryah thayyibah selain sebagai subjek dan objek, tetapi dapat menjadi metode yang memungkinkan masyarakat terlibat aktif dan berpartisipasi dalam setiap kegiatan pemberdayaan masyarakat berbasis desa. Qaryah thayyibah menjadi subjek dikarenakan makna qaryah thayyibah itu sendiri yakni desa yang indah, baik, dan berdaya. Sementara qaryah thayyibah sebagai pendekatan berkaitan dengan proses yang dilakukan dan terbukti memberikan dampak positif terhadap kehidupan masyarakat.
Misalnya, dalam upaya meningkatkan keluarga sakinah dilakukan oleh organsiasi Aisyiyah kepada anggotanya melalui pendidikan formal dan nonformal, peningkatan ekonomi keluarga, peningkatan kesejahteraan ibu dan anak, membina hubungan dengan masyarakat luas, menerbitkan buku-buku tuntunan dan pedoman yang bermanfaat bagi masyarakat, dan perkaderan melalui penalaran kepada remaja (Salman, 1995).

Kegiatan pengabdian masyarakat yang dilakukan tim pelaksana di Desa Datar, Kecamatan Sumbang, Kabupaten Banyumas memfokuskan pada aspek-aspek pemberdayaan masyarakat. Adanya kelayanan, pemberdayaan, dan advokasi menjadi sangat penting dalam bentuk gerakan yang tidak mengedepankan profit-oriented, sebab hal tersebut menimbulkan efek yang saling membutuhkan satu sama lain dikarenakan terjalinnya tingkat kesadaran dan kepedulian baik secara individu, kelompok, ataupun lembaga. Artinya, fondasi yang harus terbangun dalam konsep pemberdayaan yang bervisi mengoptimalkan kemampuan harus meliputi tiga hal yakni: pertama, konsep silaturahmi yang bertujuan membangun lingkungan yang kondusif, sehingga sumber ekonomi yang selama ini belum tergali bisa diberdayakan secara maksimal dan bertanggung jawab secara terlembaga. Kedua, konsep kebersamaan yang sebagai upaya umat Islam untuk menciptakan kemakmuran, sebab itu diperlukan pola kemitraan yang bisa saling membantu satu sama lain. Ketiga, people contered, melibatkan partisipasi masyarakat dalam setiap pembangunan dan pemberdayaan yang menghasilkan tindakan aktif untuk samasama bertindak (Alwi, 1995).

Kegiatan pendampingan keagamaan dilakukan dengan pelatihan pengelolaan zakat. Materi dalam kegiatan ini dibagi menjadi dua bagian yakni hukum zakat dan manajemen pengelolaan zakat. Zakat secara bahasa berarti suci, tumbuh, berkah, dan terpuji, sedangkan secara istilah zakat adalah suatu ibadah wajib yang dilaksanakan dengan memberikan sejumlah kadar tertentu dari harta sendiri kepada orang yang berhak menerima sesuai dengan ketentuan syariat Islam (Muhammadiyah, 2004). Namun, banyak yang sepakat bahwa zakat bukanlah 
bentuk kedermawanan, melainkan sebuah kewajiban yang harus ditunaikan apabila sudah sampai kadar (nishab) tertentu, meski para akademisi di Indonesia memasukkan kewajiban tersebut pada filantropi Islam dikarenakan masih ditunaikan dengan bentuk kerelaan dan kesadaran individu tanpa sangsi sosial bagi tidak menunaikannya (Latief, 2010). Dalam sudut pandang paradigmatik zakat sebagai salah satu intrumen rukun Islam memiliki dampak ekonomi dan sosial yang signifikan dalam mengentasan kemiskinan, sehingga para penerima zakat terutama kaum miskin secara perlahan diberdayakan ke dalam berbagai sektor strategis yang pada akhirnya dapat menjadi donatur atau para muzaki baru.

Materi pelatihan pengelolaan zakat ini dilakukan dengan memberikan materi ke dalam beberapa sesi materi dengan menggunakan metode parsipatoris dialogis. Di mana para peserta pelatihan yang merupakan Takmir Masjid/Musala dan RT Se-Desa Datar diberikan kesempatan untuk mengadakan tanya jawab dan sharing dengan pemateri terkait materi yang disampaikan, sehingga terjadi dialog antara pemateri dengan peserta pelatihan. Pertanyaan yang muncul berkaitan dengan hukum dan pengelolaan zakat pertanian dan perdagangan yang selama ini menjadi sumber utama masyarakat Desa Datar.

Dampak kegiatan pelatihan ini yakni semakin meningkatnya pemahaman peserta mengenai pengelolaan zakat dan dukungan Kepala Desa Datar yang berkomitmen ingin mendirikan Unit Pengumpul Zakat (UPZ) yang diintegrasikan dengan BAZNAS Banyumas, di samping tetap memberikan kesempatan seluasluasnya kepada lembaga amil zakat (LAZISNU, LAZISMU, dan lainnya) untuk tetap melakukan pengelolaan zakat di Desa Datar yang pada akhirnya terjadi sinergisitas antara pemerintah, masyarakat, dan organisasi keagamaan.

Faktor pendorong pendampingan keagamaan dengan pelatihan pengelolaan zakat adalah salah satu bentuk kebutuhan masyarakat Desa Datar dalam menggali potensi dan mengelolaannya secara terlembaga. Di sampng itu, peran aktif pemerintah Desa Datar juga patut diapresiasi, karena setiap pekan di bulan Ramadan melakukan turun ke bawah (turba) dengan mengunjungi Musala/Masjid di Desa Datar, selain untuk menyerap aspirasi, tetapi juga melakukan pendampingan keagamaan, sedangkan dukungan masyarakat ditunjukkan dengan komitmen untuk mengikuti rangkaian kegiatan dan mendukung kegiatan keagamaan, khususnya pengelolaan zakat secara terlembaga. Berkaitan faktor penghambat dalam kegiatan ini tentu berkaitan dengan masih belum adanya lembaga zakat profesional yang beroperasi di Desa Datar, sekalipun ada lembaga amil zakat yang mengumpulkan zakat, namun secara perlahan karena persoalan teknis kurang masif. Selain itu, warga wajib zakat juga tidak terlalu banyak sebagaimana di perkotaan, sehingga penggalian potensi zakat masih dilakukan secara temporer.

Pendampingan kepemudaan lakukan pada pengembangan sikap dan kemampuan remaja dan pemuda kegiatan yang telah terlaksana di Desa Datar yakni adanya sosialisasi penyakit menular dan bahaya narkoba bagi remaja yang hampir menjadi permasalahan bersama di berbagai tempat di Indonesia, hal ini disebabkan oleh ketidaktahuan, kurangnya informasi, dan kurangnya pendidikan narkoba kepada remaja yang dimulai dengan tahap coba-coba, pemakai sosial, situasional, dan ketergantungan (Hartini et al., 2018). Pemateri dalam kegiatan ini berasal dari Badan Narkotika Nasional (BNN), Babinkamtibmas, dan Babinsa. Sementara pendampingan kemampuan yakni pengembangan minat dan bakat dilakukan cara diskusi dengan pengurus tim kesebelasan Garuda Datar yang diakhiri pemberian perangkat sepakbola. Dimana tim kesebalasan Garuda Datar telah mengikuti beberapa turnamen, baik tingkat desa, kecamatan, dan kabupaten.

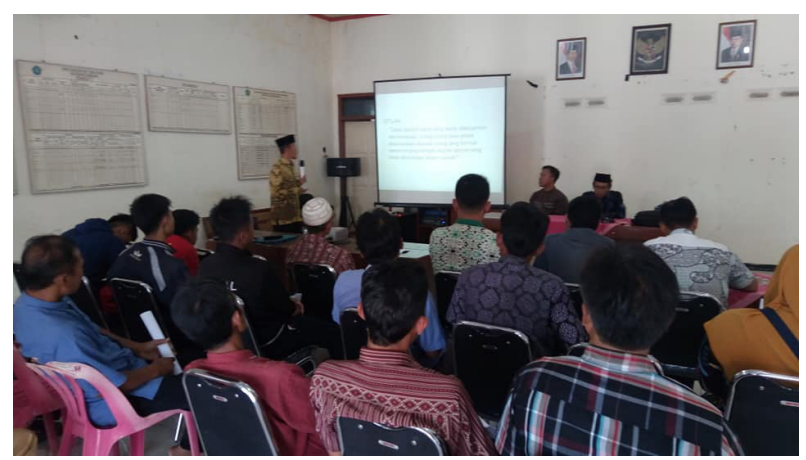

Gambar 2. Sosialisasi Pengelolaan Zakat Kepada Takmir Masjid/Musala Dan RT Se-Desa Datar 


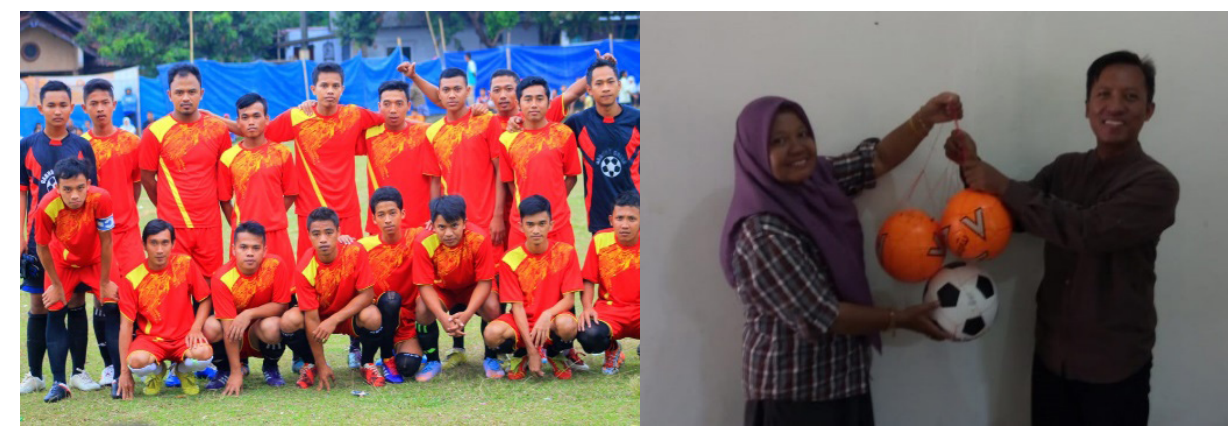

Gambar 3. Tim Kesebelasan Garuda Datar dan Pemberian Bola Kepada Pengurus

Kegiatan pendampingan ini lebih bersifat persoalan yang kompleks dalam kehidupan remaja dan pentingnya spronsor utama dalam sebuah kesebelasan. Hal ini tentu saja tidak bisa dilakukan hanya beberapa kali pertemuan tindakan edukatif, tetapi secara berkesinambungan terhadap kompleksitas yang dihadapi para remaja dan pemuda di Desa Datar. Adanya respon positif dari para remaja untuk dapat terlibat dalam pencegahan penyakit menular dan bahaya narkoba patut diapresiasi oleh semua pihak, sedangkan untuk tim kesebelasan Garuda Datar, kini memiliki pengurus tersendiri dimana perangkat desa juga terlibat dalam struktur kepengurusan, serta telah memiliki beberapa lapis, sehingga tim ini dapat dimainkan di setiap ajang kompetisi yang diikuti.

Faktor pendorong dalam kegiatan ini adalah apresiasi dan antusiasme remaja dan pemuda Desa Datar untuk terlibat aktif dalam penanggulangan penyakit menular dan bahaya narkoba bagi remaja, hal tersebut ditandai dengan ada keterlibatan kelembagaan karang taruna dalam upaya penanggulangan penyakit remaja tersebut. Sementara tim kesebelasan Garuda Datar merupakan tim yang sudah solid dan siap berkompetisi dalam ajang kompetisi sepak bola, baik lokal maupun regional. Faktor penghambat dalam kegiatan ini adalah kurang terbukanya para pelaku dan korban mengenai tindakan penyalahgunaan narkoba yang berakibat data riil korban atau pelaku. Sementara untuk tim kesebelasan Garuda Datar belum adanya sponsor utama klub, sehingga menjadi kendala tersendiri dalam proses pelaksanaan latihan maupun turnamen yang akan diikuti.

Kegiatan pendampingan kesehatan dan ekonomi masyarakat Desa Datar terbagi atas dua program, pertama, adanya pelatihan kader posyandu, hal ini berkaitan dengan keberadaan posyandu yang masih belum dimanfaatkan secara optimal oleh para ibu balita, sehingga turut memberikan kotribusi terhadap meningkatnya tingkat kematian balita, oleh sebab itu dibutuhkan peran aktif oleh para kader posyandu (Subagyo \& Wahyuningsih, 2015). Adanya kegiatan peningkatan kapasitas kader Posyandu bertujuan meningkatkan peran aktif kader posyandu dan meningkatkan tingkat kesehatan masyarakat, khususnya balita dan batita menjadi lebih baik yang ditandai tumbuh dan kembang anak yang positif sehingga tingkat kematian balita dapat dikurangi. Kedua, peningkatan kesejahteraan taraf hidup masyarakat melalui pelatihan diversifikasi pangan kepada masyarakat Desa Datar yang bertujuan agar dapat memanfaatkan sumber pangan alternatif di luar bahan pangan utama (padi). Dalam proses kegiatan ini para peserta diberikan materi oleh Pokja 3 PKK Desa Datar, kemudian peserta diberikan kesempatan untuk mempraktikan pangan alternatif tersebut ke dalam berbagai bahan olahan makanan, yang tujuannya setelah kegiatan pelatihan diversifikasi pangan peserta dapat menerapkannya di rumah dan dalam jangka panjang menjadi sumber penghasilan berbasis industri rumah tangga. Dalam sudut kebijakan pemerintah mengenai pangan, salah satu cara yang dilakukan oleh Kementerian Pertanian dalam peningkatan ekonomi masyarakat yakni dengan mengadakan program Program Desa Mandiri Pangan (Demapan) yang bertujuan untuk mengurangi rawan pangan dan gizi melalui pendayagunaan sumber daya, kelembagaan, dan kearifan lokal pedesaan, kemudian disinergikan dengan dan Program Usaha Pengembangan Agribisnis/PUAP (Darwis \& Rusastra, 2016) 


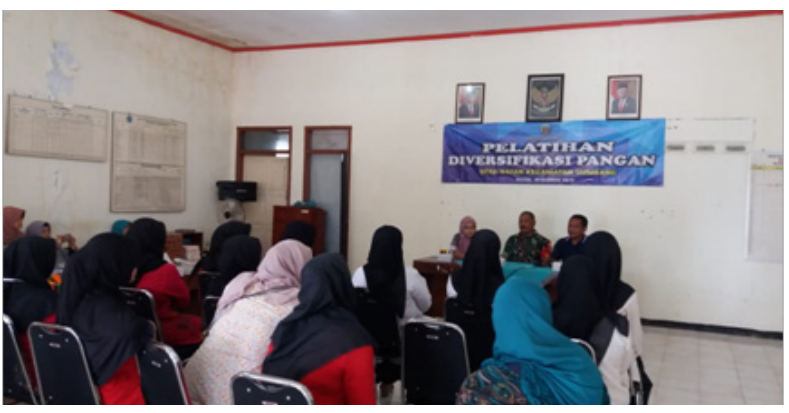

Gambar 4. Pelatihan Diversifikasi Pangan

Faktor pendorong dalam kegiatan ini salah satunya karena kader Posyandu Desa Datar telah terbentuk, sehingga mudah dalam melaksanakan kegiatan yang ada di posyandu, sedangkan diversifikasi pangan masih bisa dioptimalkan karena Desa Datar merupakan daerah sentra hewani dan nabati. Faktor penghambat dalam proses kegiatan ini lebih pada kontinyuitas para orang tua yang memiliki balita untuk bisa datang ke posyandu, sedangkan untuk diversifikasi pangan tidak hanya untuk pangan konsumsi pribadi (domistik), tetapi pada pangan yang dapat dijual untuk peningkatan kesejahteraan dan ekonomi masyarakat Desa Datar Kecamatan Sumbang Kabupaten Banyumas.

Integrasidankolaborasiseluruhstakeholders dalam proses pemberdayaan masyarakat menjadi salah satu indikator dalam keberhasilan berbagai kegiatan yang dilaksanakan, hal ini disebabkan adanya kompleksitas masalah yang dihadapi, skala prioritas kebutuhan masyarakat, dan target luaran yang hendak dicapai. Maka, dengan adanya kolaborasi antar stakeholders yang melibatkan pemerintah desa, pemerintah kecamatan, dinas koperasi, dinas pendidikan, dan UMKM yang dapat berimplikasi partisipasi masyarakat di bidang ekonomi, kesehatam, sosial, dan terjaminnya kegiatan kelompok dan organisasi (Ciptaningsih \& Nurcahyanto, 2018). Upaya pengabdian masyarakat yang dilakukan oleh tim pelaksana dalam pemberdayaan masyarakatdengan pendekatan qaryah thayyibah di Desa Datar, Kecamatan Sumbang, Kabupaten Banyumas, barangkali tidak menyelesaikan masalah utama yang dihadapi oleh masyarakat desa (kemiskinan), namun adanya edukasi dalam bentuk pelatihan dan pendampingan yang dilakukan secara perlahan harapannya dapat mengurai salah satu permasalahan yang dihadapi.

\section{KESIMPULAN}

Kegiatan pengabdian masyarakat yang dilaksanakan tim pelaksana melalui pemberdayaan masyarakat berbasis pendekatan qaryah thayyibah pada Desa Datar Kecamatan Sumbang Kabupaten Banyumas memfokuskan program kepada tiga aspek, yakni: pertama, pendampingan keagamaan dilakukan dengan pelatihan pengelolaan zakat. Materi dalam kegiatan ini dibagi menjadi dua bagian yakni hukum zakat dan manajemen pengelolaan zakat. Kedua, pendampingan kepemudaan yang termanifestasi dalam bentuk sosialisasi penyakit menular dan bahaya narkoba bagi remaja dengan pemateri berasal dari Badan BNN, Babinkamtibmas, dan Babinsa. Selain itu, pendampingan yang berupa pengembangan minat dan bakat dilakukan cara diskusi dengan pengurus tim kesebelasan Garuda Datar yang diakhiri pemberian perangkat sepak bola. Ketiga, pendampingan kesehatan dan ekonomi masyarakat yang termanifestasi dalam bentuk adanya kegiatan peningkatan kapasitas kader posyandu agar tingkat kesehatan masyarakat, khususnya balita agar tumbuh dan kembang anak yang positif, sementara upaya peningkatan sejahteraan taraf hidup masyarakat dilakukan dengan pelatihan diversifikasi pangan yang bertujuan masyarakat Desa Datar dapat memanfaatkan sumber pangan alternatif diluar bahan pangan utama (padi), setelah pelaksanaan kegiatan para peserta dapat menerapkannya di rumah dan dalam jangka panjang menjadi sumber penghasilan berbasis industri rumah tangga.

\section{PERSANTUNAN}

Terima kasih kepada LPPM Universitas Muhammadiyah Purwokerto yang telah memberikan dukungan dan pendanaan terhadap program pada masyarakat yang tim pelaksana telah laksanakan. Terima kasih dan apresiasi terhadap Pemerintah Desa Datar, Kecamatan Sumbang, Kabupaten Banyumas yang telah menjadi mitra pelaksanaan pengabdian masyarakat, sehingga memberikan temuantemuan dan diskusi dalam penyelesaian masalah yang dihadapi. 


\section{REFERENSI}

Abulias, MN. Utarini, SR. Winarti, E. (2014). Manajemen Kualitas Media Pendederan Lele pada Lahan Terbatas dengan Teknik Bioflok. Jurnal MIPA, 37(1), 16-21.

Adawiah, R. (2013). Aisyiyah dan Kiprahnya dalam Pembinaan Keluarga Sakinah. Mu'adalah; Jurnal Studi Gender Dan Anak, 1(2).

Alwi, S. (1995). Konsep dan Strategi Pemberdayaan Umat Pendekatan Sosial Ekonomi. Majalah Ilmiah Unisia.

Bahrudin, A. (2007). Pendidikan Alternatif Qaryah Thayyibah. LKIS PELANGI AKSARA.

Ciptaningsih, R., \& Nurcahyanto, H. (2018). Kolaborasi Stakeholders dalam Pemberdayaan Masyarakat (Studi Kasus di Desa Wonoyoso, Kecamatan Pringapus, Kabupaten Semarang). Journal of Public Policy and Management Review, 8(1), 97-112.

Dahl, R. A. (1989). Democracy and its Critics. Yale University Press.

Dardjito, Endo. Nurcahyo, P. J. (2010). Studi tentang Usaha-Usaha Peningkatan Taraf Kesehatan Masyarakat di Desa Datar Kecamatan Sumbang Kabupaten Banyumas Tahun 2009. Jurnal Kesmas Indonesia, 3(1), 76-185. https://doi.org/10.18860/ling.v5i1.609

Darwis, V., \& Rusastra, I. W. (2016). Optimalisasi Pemberdayaan Masyarakat Desa melalui Sinergi Program Puap dengan Desa Mandiri Pangan. Analisis Kebijakan Pertanian, 9(2), 125-142.

Hartini, S., Sudrajat, T., \& Pratama, T. S. (2018). Pendidikan Narkoba terhadap Pelajar untuk Mewujudkan Generasi Bebas Narkoba. Prosiding Seminar Nasional Dan Call for Papers, 359-365. http://jurnal. lppm.unsoed.ac.id/ojs/index.php/Prosiding/article/viewFile/735/673

jateng.antaranews.com. (n.d.). Dua kurir dan bandar sabu-sabu di Banyumas terancam hukuman mati. https://jateng.antaranews.com/berita/268872/dua-kurir-dan-bandar-sabu-sabu-dibanyumas-terancam-hukuman-mati

Latief, H. (2010). Melayani Umat Filantropi Islam dan Ideologi Kesejahteraan Kaum Modernis. In Gramedia Pustaka Utama.

Makhrus. (2018). Dinamika dan Aktivisme Filantropi Islam dalam Pemberdayaan Masyarakat. Litera.

Muhammadiyah, D. S. L. (2004). Pedoman Zakat Praktis. Suara Muhammadiyah, Yogyakarta.

PP Aisyiyah. (2012). Panduan Teknis Pelaksanaan Program Qaryah Thayibah. PP Aisyiyah.

Puspita, H. (2016). Aisyiyah dan Ekonomi Kreatif: Usaha Pemberdayaan Perempuan melalui Pengembangan Kewirausahaan Keluarga di Kecamatan Tanggulangin Kabupaten Sidoarjo. Prosiding Seminar Nasional Ekonomi Dan Bisnis, 383-393.

Salman, I. (1995). Peran Organisasi Aisyiyah dalam mewujudkan Keluarga Sakinah di Kalangan Anggota. 27182.

Sodiq, A., \& Yuwono, P. (2016). Pola Pengembangan dan Produktivitas Sapi Potong Program Kemitraan Bina Lingkungan di Kabupaten Banyumas dan Cilacap Provinsi Jawa Tengah. Jurnal Agripet, 16(1), 56. https://doi.org/10.17969/agripet.v16i1.3861

Subagyo, W., \& Wahyuningsih, D. (2015). Peran Kader dalam Memotivasi Ibu Balita Berkunjung ke Posyandu. Soedirman Journal of Nursing, 10(3), 158-166. 